„Ante Portas - Studia nad Bezpieczeństwem”

2019, Nr 1(12)

DOI: $10.33674 / 220192$

George ZVIADADZE ${ }^{1}$

Georgia

\title{
THE BEGINNING OF THE POST-MODERN GEOPOLITICAL EPOCH AND THE PECULIARITIES OF THE SYSTEM OF CONTEMPORARY INTERNATIONAL RELATIONS IN THE $21^{\text {ST }}$ CENTURY
}

\begin{abstract}
:
After transformation of unipolarity and reformatting world order system, a question been forwarded on how new system is to be founded on. As it is known classical international relations system developed since Westphalia Agreement of 1648 has been composed mainly by the state as key actors of international politics. The system has been developed two type of regimes: soft bipolarity and balance of power interchanged in several period of time consequently. One of the characteristic features of globalization is a fundamental change of the international system and world order. It differs from the world of post-Cold War period with the stance of different actors of international relations on each other as well as with the forms of sharing power and that of interconnections. In that context there were four phases of the international relations systems: the system of Westphalia, the system of Vienna, the system of Versailles, the system of Yalta-Potsdam and later international relations were transformed into bipolarity one. Since demolishing classical Cold War order and entering into new epoch of anarchic scenario, the states as key actors of the system have been diminishing in favour of so-called "nonstate actors". However, in the international system of the $21^{\text {st }}$ century, the nationstate still has particular functions. It represents the dominant element of the world politics which can influence the behaviour of the population and non-state actors.
\end{abstract}

Keywords:

international relations, international law, international system, balance of power, non-state actors, soft bipolarity, treaty of Westphalia, nation-state, EU, League of Nations

\footnotetext{
${ }^{1}$ George Zviadadze, PhD student in political science, Faculty of Social Sciences of the International University of the Caucasus; PhD in Theology, Protopresbyter, Rector of Tbilisi Theological Academy and Seminar. Email: giorgi@globalmail.ge
} 


\section{Introduction}

The principal element of the contemporary international system is the state; but the nature of international relations is defined by the quality of the stance and relations between the subjects (states, international organizations, etc.). The nature of international relations, the level of interdependence of the states and other subjects of international law is so tight and so interdeterminate that they may be appropriately called an international system. It is a known fact that international relations have a systemic nature, representing a unity of subsystems of various types. The international system is a complex and closed one. Each of its elements, for instance a state, is a system itself in which various groups and interests may be conceived as subsystems. The foreign policy, which states construct, is the form of interconnections and its nature determines the mould of the system ${ }^{2}$.

The external-political objectives and orientations of the principal elements of the international system (the leading states) have a significant impact on its mould. Specifically, the interrelationship of superstates may absolutely change the structure of the international system.

Researchers of the international system mark out two main and fundamental systemic processes - conflict and cooperation, which in effect determine the mould of the system, and actions of states appear to be their reaction to these processes ${ }^{3}$. For the proper regulation of the mentioned processes and the international system, at large, international organizations are established, norms of international law are formulated, etc. According to the structure, different types of the international structures are marked out and the militant stance of states on one another is considered as main criterion. According to the majority opinion among researchers, basically only two types occur in practice:

- Soft bipolar (the world is divided between two poles where a certain group of countries can be relatively independent and not belong to any of the poles);

- The balance of power where its distribution among several poles engenders stability and, consequently, sustainability ${ }^{4}$.

\footnotetext{
${ }^{2}$ K. A. Mingst, I. M. Arreguin-Toft, Essentials of International Relations, New YorkLondon 1999, pp. 116-123.

3 A. Clarckson, Conflict and Cooperation in International Relations, February 2011, <https://www.e-ir.info/2011/02/01/conflict-and-cooperation-in-international-relations/> (30.06.2019).

${ }^{4}$ A. E. Varisco, Towards a Multi-Polar International System: Which Prospects for Global Peace?, <https://www.e-ir.info/2013/06/03/towards-a-multi-polar-internationalsystem-which-prospects-for-global-peace/> (30.06.2019).
} 
After the dismantling of the social system and the breakup of the Soviet Union from the soft bipolar system, the world has altered into a multipolar system. However, since the USA has remained the only superpower, some researchers call the contemporary system unipolar (of one pole) and envisions its alteration into a hierarchical system, dependant on the USA. According to a more optimistic prognosis, the world is a future universal system where international organizations, international law and international morals will be the determining factors for the regulation and sustainability of the international system.

One of the characteristic features of globalization is a fundamental change of the international system and world order. It differs from the world of post Cold War period with the stance of different actors of international relations on each other as well as with the forms of sharing power and that of interconnections.

\section{The International Systems in History}

A historical analysis of the international system in the period of recent history gives an opportunity to mark out several stages of circumstances in the international relations.

The System of Westphalia (1648) which, in effect, turned the nation-states into the only actors of international relations and, by doing so, changed the previous actors (dynasties, city-states, etc.). This system remained unchanged since the states represented and represent today also the main actors of the international relations. Several decades ago, before the beginning of intensive globalization, world politics was mostly organized as based on the so called the System of Westphalia. The name originates from the Treaty of Westphalia (1648) which represents the earliest official expression of primary principles which were dominant in Europe for three centuries. In the $19^{\text {th }}-20^{\text {th }}$ centuries, the states gradually took the form of national states, the terms "international" and "all states inclusive" was widely in use and the System of Westphalia was often described as an "international system".

The System of Westphalia represented the framework of rule. It was a way of establishing, strengthening and supervising of a certain social order. It was founded on the principle of statehood and sovereignty. The statehood meant that the world was divided into territorial parts, each of which was ruled by an independent government. This modernized state was a centralized, formally organized social governmental apparatus which used legal monopoly in the form of armed violence within its borders. The System of Westphalia was also a sovereign system, which means that it executed all-inclusive, supreme, unrestricted and exclusive control within the frames of a definite territory. Allinclusive rule means that a sovereign state has its jurisdiction over any kind of 
activity within its own borders. The supreme rule means that there does not exist a government higher than they and the sovereign state has the decisive word within the framework of the given territory. Unrestricted rule means that despite the fact that in the epoch of the System of Westphalia, at times debates were held on the obligation of humanitarian intervening, the right of the states on the total jurisdiction was considered as impregnable for other states. There does not exist any "shared sovereignty".

It must be underscored that the System of Westphalia was a historical phenomenon. In other words, the system of sovereign states created a special frame of rule which was established as the result of specific circumstances in a certain period. The statehood based on sovereignty is not a natural phenomenon dependant on time. Concerning the geopolitical order, according to this system the disintegration of Germany and the leading role of France on the European continent were legalized. The subsequent strengthening of England and her coming to the stage as a straightforward hegemon and the loss of positions by France caused a new contention (Napoleonic Wars) which inaugurated a new international system ${ }^{5}$.

The System of Vienna (1815) fundamentally changed the political map of Europe. A new balance of powers emerged under the hegemony of England. The foremost states became Austria and Prussia. The German states made up 38 in all (according to the order of Wesphalia, their number had been 300). The establishment of the unified literary language and the common national consciousness lay the foundation to the process of the unification of German states. The shift of North Italy under the rule of Austria galvanized the beginning of the actions for national independence in Italy and the unification of Italy. Further, the unification of Germany and the establishment of the State of Italy, as well as the actions for national independence in the Ottoman Turkish and Austro-Hungarian Empires significantly changed the balance of powers which caused a new contention. This drew humankind into $\mathrm{WWI}^{6}$.

The System of Versailles (1919) was the messenger of a new geopolitical system in Europe which was to strengthen the hegemony of Great Britain and France, whereas Germany was to be left in the position of a second rate state. Apart from this, her colonies were to be shifted under the rule of the victorious countries. New buffer states were emerging between Russia and Germany as a kind of section to block the possibility of consolidation of contacts between Russia and Germany (a continental block). A significant novelty was the

\footnotetext{
${ }^{5}$ Treaty of Westphalia; 24.10.1648. Peace Treaty between the Holy Roman Emperor and the King of France and their respective Allies, published on the International Relations and Security Network: Primary Resources in International Affairs, <https://is.muni.cz/ el/1423/podzim2008/MVZ430/um/Treaty-of-Westphalia.pdf> (30.06.2019).

${ }^{6}$ S. Ghervas, What was the Congress of Vienna?, "History Today", Volume 64 Issue 9 September 2014.
} 
establishment of the universal international organization the League of Nations which was to perform the duties of the guarantor of peace and security in the world. The System of Versailles was very volatile and utopian and therefore it only existed for 20 years. The victory of Nazism in Germany, the Fascist dictatorship in Italy and the militarization of Japan turned the League of Nations into a fictitious organization, leading the world up to WWII ${ }^{7}$.

The Yalta-Potsdam System (1945) was an official confirmation of the post World War reality. The world was split into two camps, with two superpowers at the head each - the United States of America and the Soviet Union, respectively. For the first time in history, the driving forces of the world politics emerged beyond the boundaries of Europe. The Cold War era began and the system assumed a distinctive bipolar mould and, until the mid-50s of the $20^{\text {th }}$ century, it represented a hard bipolar system, later (when a group of unsupportive countries was established, China broke up with the Soviet Union and the idea of the United Europe became more and more realistic), it turned into a soft bipolar system. At the turn of the 80s, the events that took place in the Soviet Union were followed by the disintegration of the Socialist System and the Soviet Union itself. The message was that the Cold War had ended and the Yalta-Potsdam System stopped its existence ${ }^{8}$.

Today, the world is in a period of new geopolitical changes. Unlike all the other systems that existed before, the Yalta-Potsdam System has not ended after the war, and neither has the peace treaty determined the balance of powers. Therefore, the new geopolitical order has not been organized yet, and still, the fundamental issue is quite another matter. The Post Cold War period differs from the periods prior to it substantially. The role of a national state as of an actor of the international relations is diminishing. Globalization has brought about the rapid growth of the role of transnational subjects and the civil sector. Many researchers consider that the core idea of the System of Westphalia is being changed, i.e. states lose their significance in the international system. Exactly for this reason, the events characteristic of the international system and the world order in the epoch of globalization draw great interest.

As it has already been mentioned, the international system is a complex system, consisting of various subjects, among them, states. The foundation for the international system was laid by the Treaty of Westphalia, signed in 1648. Prior to that, the organization of the European Medieval political government was based on unclearly regulated religious hierarchy. The Treaty of Westphalia introduced the notion of sovereignty which in essence meant that the ruler

\footnotetext{
7 Treaty of Versailles, <https://www.britannica.com/event/Treaty-of-Versailles-1919> (30.05.2019).

${ }^{8}$ S. M. Plokhy, Yalta: The Price of Peace, London 2011; M. Neiberg, Potsdam: The End of World War II and the Remaking of Europe, New York 2015.
} 
of the state did not recognize another governor with an equal status to his or the one of a higher rank than his, whether in the country or beyond it. Accordingly, the core element of the system has become the nation-state with its sovereignty and power. In the world policy, the state assumed exclusive rights as the main player of the international system who determined the world policy according to its own interests. Many years have passed since the Treaty of Westphalia and one wonders if the circumstances or the role of the nation states have changed. It should be observed, that alongside the state, there have also emerged other subjects in the system, which are international organizations, transnational corporations, etc. They, too, have a significant role and function in world politics.

\section{Contemporary International Relations}

Today, especially under the circumstances of globalization, states have come close to each other to such extent that, having found common interests and established cooperating organizations, it may be said that the role of the state has relatively weakened. We have to deal with a new world where decisions are not made solely in favour of the interests of one state, i.e. the role of the state as of the main actor of the international policy is questionable. However, it should also be mentioned, that today we are not facing the tendency of a complete disappearance of the state, rather it is a weakening of its role. The aforementioned has been caused by the radical growth of the role of international organizations on the scene of world politics. Not only the growth of their role but also the growth of their number is to be underscored.

Today, the states can cooperate, they can solve their problems and take necessary decisions in order to maintain peace and security by negotiations around the table. In reality, an international organization has been established for this objective and as time passes, it fulfils its responsibilities on a more regular basis. For instance, the European Union can be named, which is the most outstanding and successful case of the integration of states. The common attributes of its member states are: common market, currency, economics, unimpeded crossing of borders for products as well as for individuals, cooperation in the spheres of justice and internal matters of states, etc. The EU has connected states to each other in such a way that none of them can ever act at its own will and for attaining its private ambitions on the arena of international politics. To conclude, being a member of the EU for a state means to dispense with a part of sovereignty which perhaps was a less conceivable matter earlier.

Apart from international organizations, the growth of the role of transnational corporations in the world politics is also very important. Although, the headquarters of such corporations is in one state, we should not 
forget that its branches encompass many countries of the world. This means that the corporation produces its product for many countries of the world and, determining their economy locally, creates a chain in the global economy. This influences international relations, totally, since economy and production are essential for the state and transnational organizations suggest to them the rules of play and means of high standards to carry them out.

It is impossible to speak about the world as it is today without globalization. As its pace has gained speed, which is also expressed in the growth of the aforementioned organizations and transnational relations and also in such close contacts of the states which can bring about a complete elimination of borders. Possibly, it represents a process stretched in time. However, purportedly, the state will maintain its standing for quite a long time, but one cannot deny the fact that globalization has altered sovereignty, the scale of which in political as well as in cultural, economical, communicative, informational and other spheres, has profoundly grown. Although the state governmental rule has been maintained, it is weakened due to its close attachment to sub-state, super state, marketing and civil rule. Therefore, globalization creates such a world where states connected to each other by cultural, political, economical or social unities cannot maintain such policy, which was established by the order of Westphalia.

Despite the aforementioned, I am convinced that in the $21^{\text {st }}$ century, the role of the state does not weaken. On the contrary, it grows or the role of the state does not lose its significance. The core of the arguments to testify this supposition is that the main element in the international relations is the national interest of the state and her sovereignty. Although the states handle their sovereignty and therefore, defend it, at the same time, they join international organizations, and consequently, in accord with the statute of these organizations, they have to give up some part of their sovereignty. In the international system of the $21^{\text {st }}$ century, the nation-state still has particular functions. It represents the dominant element of the world politics which can influence the behaviour of the population and non-state actors.

\section{Conclusion}

The contemporary international system represents a system of relations, held on the international level, which encompasses the interactions of state and non-state actors (international organizations, transnational corporations, international non-governmental organizations). The states are trying to carry out their own national interests in opposition of the objective factors, where conflict and cooperation are equally potential. For many years, international organizations have been trying to construct mechanisms for ruling out and regulating of conflicts. In the aforementioned process, a profound role is held 
by the states who also establish rules of contacts and behaviour within the international organizations in the entire international system. In accordance with it, we can conclude that in the international system of the $21^{\text {st }}$ century, world politics is determined by relations among the states, however, it does not diminish the role of international organizations whose source of legitimacy are still the states.

\section{BIBLIOGRAPHY:}

$\checkmark$ Clarckson A., Conflict and Cooperation in International Relations, February 2011, <https://www.e-ir.info/2011/02/01/conflict-and-cooperation-in-international-relations/>

$\checkmark$ Ghervas S., What was the Congress of Vienna?, "History Today", Volume 64 Issue 9 September 2014

$\checkmark$ Mingst K. A., Arreguin-Toft I. M., Essentials of International Relations, New York-London 1999

$\checkmark$ Neiberg M., Potsdam: The End of World War II and the Remaking of Europe, New York 2015

$\checkmark$ Plokhy S. M., Yalta: The Price of Peace, London 2011

$\checkmark$ Treaty of Westphalia; 24.10.1648. Peace Treaty between the Holy Roman Emperor and the King of France and their respective Allies, published on the International Relations and Security Network: Primary Resources in International Affairs, <https://is.muni.cz/el/1423/ podzim2008/MVZ430/um/Treaty-of-Westphalia.pdf>

$\checkmark$ Treaty of Versailles, <https://www.britannica.com/event/Treaty-ofVersailles-1919>

$\checkmark$ Varisco A. E., Towards a Multi-Polar International System: Which Prospects for Global Peace?, <https://www.e-ir.info/2013/06/03/ towardsa-multi-polar-international-system-which-prospects-for-global-peace/> 